\title{
Analisis K3 pada Sistem Pengangkutan Sampah Rumah Tangga di Jalan Garuda Kota Palangka Raya
}

\author{
Rida Respati \\ Program Studi Teknik Sipil Universitas Muhammadiyah Palangkaraya
}

\begin{abstract}
ABSTRAK. Angka kecelakaan kerja yang tinggi di setiap pekerjaan menunjukkan bahwa kecelakaan kerja banyak disebabkan oleh human error. Tingginya angka kecelakaan kerja di sektor ini karena kesadaran dari penyedia jasa, dan diri sendiri terhadap kecelakaan kerja masih rendah. Analisis Keselamatan dan Kesehatan Kerja (K3) di pada Sistem Pengangkutan Sampah Rumah Tangga di Jalan Garuda Kota Palangka Raya mencoba menjawab permasalahan apa saja yang telah dilakukan untuk mencegah kecelakaan kerja. Penelitian ini bertujuan untuk mengetahui apakah penerapan K3 pada Sistem Pengangkutan Sampah Rumah Tangga di Jalan Garuda Kota Palangka Raya ini berhasil dalam upaya pencegahan kecelakaan kerja. Pengumpulan data bersumber dari koran, jurnal ilmiah, Tesis dan peraturan-peraturan yang berhubungan dengan Keselamatan dan Kesehatan Kerja (K3). Disamping itu, data juga diperoleh dari wawancara (interview) yang kompeten dan pengamatan (observation). Hasil identifikasi menunjukkan, bahwa penerapan K3 pada Sistem Pengangkutan Sampah Rumah Tangga di Jalan Garuda Kota Palangka Raya hanya berhasil dalam upaya pencegahan kecelakaan kerja dengan dukungan adanya ramburambu lalu lintas, dan alat pelindung diri seperti baju kerja, sarung tangan, septu kerja, dan masker. Sedangkan penerapan K3 yang belum di dukung tidak ada sosilisasi K3, kurangnya himbauan-himbauan K3 dan tidak ada petugas keamanan masih kurang berhasil. Namun secara keseluruhan, bahwa penerapan K3 di paket ini cukup berhasil dalam upaya pencegahan kecelakaan kerja. Untuk itu, disarankan agar melengkapi semua alat pelindung diri (baju kerja, sarung tangan, sepatu dan helm), melakukan sosilisasi K3, himbauan-himbauan K3 dan petugas keamanan. Kemudian, upayakan adanya komitmen bersama dalam menjalankan K3 dan membuat aturan atau sanksi dalam menjalankan K3 sehingga diharapkan dapat mencegah tidak ada kecelakaan kerja atau nol kecelakaan (zero accident).
\end{abstract}

Kata Kunci: analisis K3, pengangkutan sampah

\section{PENDAHULUAN}

Palangka Raya merupakan salah satu kota sekaligus ibu kota provinsi Kalimantan Tengah. Memiliki predikat sebagai "Kota Cantik" karena keindahan tata kota dan kebersihan kotanya. Menyandang predikat sebagai "Kota Cantik" kota Palangka Raya tidak lepas dari penanganan Pemerintah Kota
Palangka Raya dalam menangani dan menata sedemikian rupa sehingga Palangka Raya memiliki tata kota yang apik dan kebersihan kota yang memanjakan mata. Kota dengan luas $2.400 \mathrm{~km}^{2}$ memiliki jumlah penduduk yang semakin bertambah setiap tahunnya Kota dengan luas $2.400 \mathrm{~km}^{2}$ memiliki jumlah penduduk yang semakin bertambah setiap 
tahunnya. Kota Palangka Raya terdiri atas 5 kecamatan yaitu Pahandut, Jekan Raya, Bukit Batu, Sebangau, dan Rakumpit.Berdasarkan BPS Kota Palangka Raya tahun 2012 jumlah penduduk di Kecamatan Pahandut adalah 80.324 Jiwa dengan luas wilayah 117.25 KM ${ }^{2}$ dan Kepadatan Penduduk 685.07 jiwa/KM².

Volume sampah dan jenis yang dihasilkan tergantung dari pola komsumsi suatu masyarakat dalam suatu wilayah. Semakin tinggi tingkat pendapatan masyarakat tersebut maka semakin tinggi pula volume sampah yang dihasilkan dan semakin banyak jenis sampah yang dihasilkan. Penanganan sampah tidak cukup hanya dilakukan oleh aparat pemerintah, akan tetapi harus melibatkan pihak swasta dan setiap rumah tangga dengan didukung oleh sarana dan prasarana yang memadai. Karena itu keefektifan penanganan sampah sangat tergantung pada kerjasama dan kesadaran setiap rumah tangga, masyarakat, swasta, dan pemerintah dalam menyimpan, mengumpulkan, membawa dan menimbun sampah dengan koordinasi dan pengaturan tempat pembuangan sampah yang baik.

Pengangkutan persampahan di perkotaan merupakan suatu sistem yang saling berinteraksi membentuk kesatuan dan mempunyai tujuan. Pengangkutan sampah suatu kota bertujuan untuk melayani penduduk terhadap sampah domestik rumah tangga yang dihasilkannya serta menciptakan suatu lingkungan yang baik, bersih dan sehat.

Pemerintah Kota Palangka Raya dalam mengelola sampah masih bertumpu pada pendekatan akhir (end of pipe), yaitu sampah dikumpulkan, diangkut, dan dibuang ke Tempat Pemrosesan Akhir (TPA). Sampahsampah domestik, baik dari bahan organik maupun anorganik dibuang begitu saja dalam satu bak/wadah dan tercampur satu sama lain dalam berbagai komposisi, dan kemudian melalui berbagai cara transportasi, sampah berpindah tempat mulai dari tempat sampah di rumah, TPS sampai ke Tempat Pemrosesan Akhir (TPA). Pendekatan ini akan memberatkan beban TPA dengan lahan yang terbatas. Hal ini disebabkan karena variabel luas lahan TPA adalah konstan/tetap sedangkan laju pertumbuhan dan penyebaran penduduk terus meningkat, yang berdampak juga pada peningkatan jumlah timbulan sampah yang dihasilkan. Lahan yang semakin terbatas tidak mampu mengimbangi peningkatan timbulan sampah yang terjadi sekarang maupun di masa datang.

Masalah sampah yang timbul Jalan Garuda adalah karena sulitnya pengumpulan, pewadahan, dan pengangkutan, banyaknya TPS yang awalnya dibangun didekat lahan kosong milik warga dibongkar dengan alasan dibangunya pemukiman baru dilahan tersebut, menyebabkan berkurangnya TPS sehingga warga membuang sampah sembarangan. Sedangkan kemampuan pengelola sampah dalam menangani sampah tidak seimbang dengan produksinya, sehingga menumpuk dimana-mana. Sampah yang tidak terurus dengan baik akan menyebabkan menurunnya kesehatan dan nilai lingkungan karena pencemaran air, udara, dan berkembangnya hama penyakit, sehingga permukiman penduduk di sekitar tumpukan sampah tersebut tidak layak lagi bagi penduduk. Bertumpuknya sampah maka bertumpuk pula semua bibit penyakit yang ada disana, untuk itu penulis ingin menganalisa pengunaan $\mathrm{K} 3$ (kesehatan dan Keselamatan Kerja) dalam hal pengangkutan sampah dari TPS ke tempat pembuangan akhir. Oleh karena itu perlu pembahasan mengenai keefektifan sistem pengangkutan sampah yang ada sekarang ini dalam upaya menerapkan $\mathrm{K} 3$ dan mengurangi timbulan sampah.

\section{TUJUAN PENELITIAN}

Tujuan dari penelitian ini adalah untuk mengetahui apakah penerapan pengangkutan sampah menggunakan dump truck berhasil dalam upaya pencegahan pencemaran lingkungan yang ditimbulkan dari penumpukan sampah di TPS sementara.

\section{KAJIAN PUSTAKA Definisi Sampah}

Menurut Undang-undang No.18 Tahun 2008 tentang pengelolaan sampah, sampah adalah sisa kegiatan sehari-hari manuisa dan atau proses alam yang berbentuk padat. Kemudian yang di maksud dengan sampah 
spesifik adalah sampah yang karena sifat, konsentrasi, dan atau volumenya memerlukan pengelolaan khusus.Sedangkan menurut Hadiwiyoto (Maharini, 2008), sampah adalah bahan sisa, baik bahan-bahan yang tidak di gunakan lagi (barang bekas) maupun bahan yang sudah di ambil bagian utamanya yang dari segi ekonomis. Definisi sampah yang dapat dijadikan dasar penanganan sampah, yaitu:

a. Sampah adalah bahan buangan padat atau semi padat dihasilkan dari aktivitas manusia atau hewan yang dibuang karena tidak diinginkan atau digunakan lagi (Tchobanoglous, 1993).

b. Sampah adalah limbah yang bersifat padat terdiri dari zat organik dan zat anorganik yang dianggap tidak berguna lagi dan harus dikelola agar tidak membahayakan lingkungan dan melindungi investasi pembangunan (SNI T-13-1990-F).

Berdasarkan pengertian tersebut dapat disimpulkan bahwa sampah adalah semua benda yang sudah tidak diharapkan lagi keberadaanya karena dianggap kurang berguna serta banyak menimbulkan masalah pencemaran dan gangguan pada kelestarian lingkungan.

\section{Klasifikasi Sampah}

Menurut Mukono (Silvia Gardina: 2010) karakteristik sampah meliputi:

1. Garbage yaitu jenis sampah yang terdiri dari sisa-sisa potongan hewan atau sayuran dari hasil pengolahan yang sebagian besar terdiri dari zat-zat yang mudah membusuk, lembab, dan mengandung sejumlah air bebas.

2. Rubbish terdiri dari sampah yang dapat terbakar atau yang tidak dapat terbakar yang berasal dari rumah-rumah, pusatpusat perdagangan, kantor-kantor, tapi yang tidak termasuk garbage.

3. Ashes (Abu) yaitu sisa-sisa pembakaran dari zat-zat yang mudah terbakar baik dirumah, dikantor, industri.

4. Street Sweeping(Sampah Jalanan) berasal dari pembersihan jalan dan trotoar baik dengan tenaga manusia maupun dengan tenaga mesin yang terdiri dari kertas-kertas, daun-daunan.

5. Dead Animal(bangkai binatang) yaitu bangkai-bangkai yang mati karena alam, penyakit atau kecelakaan.

6. Houshold Refuse yaitu sampah yang terdiri dari rubbish, garbage, ashes, yang berasal dari perumahan.

7. Abandonded Vehicles (Bangkai Kendaraan) yaitu bangkai- bangkai mobil, truk, kereta api.

8. Sampah Industri terdiri dari sampah padat yang berasal dari industri-industri, pengolahan hasil bumi.

9. Demolition Wastes yaitu sampah yang berasal dari pembongkaran gedung.

10. Construction Wastes yaitu sampah yang berasal dari sisa pembangunan, perbaikan dan pembaharuan gedunggedung.

11. Sewage Solid terdiri dari benda-benda kasar yang umumnya zat organik hasil saringan pada pintu masuk suatu pusat pengelolahan air buangan.

12. Sampah khusus yaitu sampah yang memerlukan penanganan khusus misalnya kaleng-kaleng cat, zat radiokatif.

\section{Sumber Sampah}

Sumber sampah pada umumnya dapat diklasifikasikan sebagai berikut (DepPU, 1994):

1. Daerah Permukiman

Pada permukiman penduduk biasanya sampah dihasilkan oleh suatu keluarga tunggal atau beberapa keluarga yang tinggal dalam suatu bangunan atau asrama. Beberapa keluarga yang tinggal dalam suatu bangunan atau asrama biasanya terdapat di kota atau daerah sub urban. Jenis sampah yang dihasilkan biasanya sisa makanan dan bahan-bahan sisa dari pengolahan makanan atau sampah basah (garbage), sampah kering (rubbish), abu dan sampah-sampah khusus.

2. Daerah Komersial (tempat-tempat umum dan tempat perdagangan)

Bersumber pada pasar, pertokoan, restoran, perusahaan dan sebagainya. 
Sebagian besar kategori sampah ini berasal dari pasar dan kebanyakan berupa sampah organik.

3. Daerah Institusi

Sumber sampah institusional adalah perkantoran, sekolah, tempat ibadah dan lembaga-lembaga non komersial lainnya. Jenis sampah yang dihasilkan sebagian besar sampah kering.

4. Industri

Sumber sampah industri berasal dari perusahaan yang bergerak di bidang industri berat, industri ringan, pabrikpabrik dan lain-lain. Jenis sampah yang dihasilkan tergantung dari bahan yang digunakan oleh industri tersebut.

5. Tempat pembangunan, pemugaran dan pembongkaran

Sampah yang dijumpai adalah sampah material atau bahan-bahan bangunan. Jenisnya tergantung dari bahan bangunan yang dipakai (bata, pecahan beton, kayu, besi beton dan sebagainya).

6. Sampah jalan dan tempat-tempat terbuka Sampah kategori ini berasal dari kegiatan penyapuan jalan-jalan dan trotoar, taman dan lain-lain. Jenis sampahnya didominasi sampah organik (daun) serta debu.

7. Rumah Sakit dan Balai Pengobatan

Sampah rumah sakit pengelolaannya ditangani secara terpisah dengan sampah lainnya karena sampahnya bersifat khusus, kemungkinan mengandung kuman penyakit menular. Sampah yang dihasilkan berupa bekas-bekas operasi, pembalut luka, anatomi tubuh, disamping sampah dapur dan kantor. Sampah ini wajib dibakar (pengolahan untuk menghilangkan kuman patogenik).

8. Lain-lain

Dari klasifikasi sumber-sumber sampah tersebut, dapat dikembangkan lagi jenis sumber-sumber sampah yang lain sesuai dengan peruntukan tata guna lahannya. Sebagai contoh misalnya, dari kandang hewan/pemotongan hewan, instalasi pengolahan air bersih, instalasi pengolahan air limbah, dan lain-lain.
Menurut Suparmi (2009) besarnya timbulan sampah yang ada dibedakan menjadi:

1. Komponen-komponen sumber sampah

Tabel 1. Besar Timbulan Sampah Berdasarkan Komponen Sumber Sampah

\begin{tabular}{|c|c|c|c|c|}
\hline No & $\begin{array}{c}\text { Komponen } \\
\text { Sumber Sampah }\end{array}$ & Satuan & $\begin{array}{l}\text { Volume } \\
\text { (liter) }\end{array}$ & $\begin{array}{l}\text { Berat } \\
(\mathrm{kg})\end{array}$ \\
\hline 1 & Rumah Permanen & org $/ \mathrm{hr}$ & $2,25-2,50$ & $0,350-0,400$ \\
\hline 2 & $\begin{array}{l}\text { Rumah Semi } \\
\text { Permanen }\end{array}$ & org/hr & $2,00-2,25$ & $0,300-0,350$ \\
\hline 3 & $\begin{array}{l}\text { Rumah Non } \\
\text { Permanen }\end{array}$ & org/hr & $1,75-2,00$ & $0,250-0,300$ \\
\hline 4 & Kantor & $\mathrm{peg} / \mathrm{hr}$ & $0,50-2,00$ & $0,025-0,100$ \\
\hline 5 & Toko/Ruko & $\mathrm{ptgs} / \mathrm{hr}$ & $2,50-3,00$ & $0,150-0,350$ \\
\hline 6 & Sekolah & $\mathrm{mrd} / \mathrm{h}$ & $0,10-0,15$ & $0,010-0,020$ \\
\hline 7 & $\begin{array}{l}\text { Jalan Arteri } \\
\text { Sekunder }\end{array}$ & $\mathrm{mhr}$ & $0,10-0,15$ & $0,020-0,100$ \\
\hline 8 & $\begin{array}{l}\text { Jalan Kolektor } \\
\text { Sekunder }\end{array}$ & $\mathrm{mhr}$ & $0,10-0,15$ & $0,010-0,100$ \\
\hline 9 & Jalan Lokal & $\mathrm{mhr}$ & $0,05-0,10$ & $0,005-0,025$ \\
\hline 10 & Pasar & $\mathrm{m}^{2} / \mathrm{hr}$ & $0,20-0,60$ & $0,10-0,30$ \\
\hline
\end{tabular}

2. Klasifikasi Kota

Tabel 2. Besar Timbulan Sampah Berdasarkan Klasifikasi Kota

\begin{tabular}{cccc}
\hline No. & \multirow{2}{*}{$\begin{array}{c}\text { Klasifikasi } \\
\text { Kota }\end{array}$} & $\begin{array}{c}\text { Volume } \\
\text { (liter/org/hari) }\end{array}$ & $\begin{array}{c}\text { Berat } \\
\text { (kg/org/hari) }\end{array}$ \\
\hline 1 & Kota Sedang & $2,75-3,25$ & $0,700-0,800$ \\
2 & Kota Kecil & $2,50-2,75$ & $0,625-0,700$ \\
\hline \multicolumn{2}{l}{ Sumber: } & Balitbang Depatemen PU, 1993 (Suparmi, 2009)
\end{tabular}

\section{Pengelolaan Sampah}

Pengelolaan sampah adalah suatu disiplin yang berhubungan dengan pengendalian terhadap timbulan, penyimpanan, pengumpulan, pemindahan dan transport, pemrosesan dan pembuangan sampah dengan cara-cara memperhatikan berbagai prinsip kesehatan masyarakat, ekonomi, konservasi, estetika dan pertimbangan lingkungan lainnya serta juga responsive perilaku masyarakat, sehingga dalam konsep pengelolaan juga terdapat unsur pengolahan sampah (Tchobanoglous, 1993). Pengolahan sampah adalah bagaimana memproses sampah menjadi wujud yang lain (misalnya kompos, daur ulang), sedangkan pengelolaan sampah merupakan suatu konsep manajemen yang lebih menyeluruh untuk mengatasi persoalan sampah. Pengelolaan sampah meliputi tahapan berikut :

1. Pewadahan, merupakan cara penampungan sampah sebelum dikumpulkan, dipindahkan, diangkut dan dibuang ke Tempat Pembuangan Akhir (TPA). 
2. Pengumpulan, merupakan proses pengambilan sampah dari tempat pewadahannya atau sumber sampah, sampai ke tempat pemisahan atau sekaligus diangkut ke TPA.

3. Pemindahan, tahap memindahkan sampah dari hasil pengumpulan ke alat angkut.

4. Pengangkutan, merupakan kegiatan pengangkutan sampah yang telah dikumpulkan di Tempat Pembuangan Sementara (TPS) atau langsung dari sumber sampah ke TPA.

5. Pengolahan, adalah proses mengolah sampah dari sumber daya yang terbuang menjadi sumberdaya yang termanfaatkan.

Seluruh subsistem di dalam sistem pengelolaan sampah harus dipandang sebagai suatu sistem yang memerlukan keterpaduan didalam pelaksanaannya. Sistem pengelolaan sampah terpadu (Integreated Solid Waste Management) didefinisikan sebagai pemilihan dan penerapan program teknologi dan manajemen untuk mencapai performansi sistem yang tinggi dengan hirarki sebagai berikut (Tchobanoglous, 1993):

1. Reduksi pada sumber (source reduction), yaitu proses minimalisasi sampah di sumber dalam hal kuantitas timbulan dan kualitas sampah terutama reduksi sampah berbahaya.

2. Daur ulang (recycling), proses daur ulang yang berfungsi untuk mereduksi kebutuhan sumberdaya dan reduksi kuantitas sampah ke tempat pembuangan akhir.

3. Transformasi buangan (waste transformation), yaitu proses perubahan fisik, kimia dan biologis sampah, dimana ketiga komponen itu akan menentukan :

- perubahan tingkat efisiensi yang diperlukan di dalam sistem pengelolaan.

- perlunya proses Recovery, Reuse dan Recycle sampah.

- Proses yang dapat menghasilkan barang lain yang lebih bermanfaat.

4. Pembuangan akhir (landfilling), sebagai akhir dari suatu aliran sampah dimana landfill diarahkan hanya untuk menerima sampah yang tidak dapat dimanfaatkan kembali.

Pengelolaan sampah pada dasarnya bertujuan untuk menciptakan lingkungan tempat manusia bermukim bersih dan sehat. Sejak dikembangkannya sistem pengelolaan sampah di Indonesia, tujuan ini diwujudkan dengan menciptakan kebersihan diatas permukaan tanah setinggi-tingginya, prinsip ini menempatkan operasi pembuangan akhir sebagai satu-satunya alternatif guna mencapai efektivitas sistem. Pengelolaan sampah bertujuan untuk (Dep. PU, 1994):

1. meringankan beban sampah perkotaan.

2. meningkatkan kualitas lingkungan dan menyelamatkan sumberdaya alam terutama sumberdaya air dan tanah.

3. pemanfaatan kembali benda-benda yang dianggap tidak berguna dan pemanfaatan energi.

Dalam pengelolaan sampah termasuk di dalamnya pengelolaan sampah merupakan suatu upaya untuk mengurangi volume sampah dengan mengubah bentuk sampah menjadi lebih bermanfaat. Pengolahan sampah adalah suatu upaya untuk mengurangi volume sampah atau merubah bentuk menjadi lebih bermanfaat, antara lain dengan cara pembakaran, pengomposan, penghancuran, pengeringan dan pendaur ulangan. (SNI-13-1990-F). Adapun teknik pengolahan sampah adalah sebagai berikut:

1. Pengomposan (Composting); adalah suatu cara pengolahan sampah organic dengan memanfaatkan aktifitas bakteri untuk mengubah sampah menjadi kompos (proses pematangan).

2. Pembakaran sampah; dapat dilakukan pada suatu tempat, misalnya lapangan yang jauh dari segala kegiatan agar tidak mengganggu. Namun demikian pembakaran ini sulit dikendalikan bila terdapat angin kencang, sampah arang abu, debu, dan asap akan terbawa ketempattempat sekitarnya yang akhirnya akan menimbulkan gangguan. Pembakaran yang paling baik dilakukan disuatu instalasi pembakaran, yaitu dengan menggunakan insinerator, namun pembakaran 
menggunakan insinerator memerlukan biaya yang mahal.

3. Recycle; merupakan salah satu teknik pengolahan sampah, dimana dilakukan pemisahan atas benda-benda bernilai ekonomi seperti: kertas, plastik, karet, dan lain-lain dari sampah yang kemudian diolah sedemikian rupa sehingga dapat digunakan kembali baik dalam bentuk yang sama atau berbeda dari bentuk semula.

4. Reuse; merupakan teknik pengolahan sampah yang hamper sama dengan recycle, bedanya reuse langsung digunakan tanpa ada pengolahan terlebih dahulu.

5. Reduce; adalah usaha untuk mengurangi potensi timbulan sampah, misalnya tidak menggunakan bungkus kantong plastic yang berlebihan.

\section{Pengangkutan}

Menurut Suelena (2011) pengangkutan adalah kegiatan operasi yang dimulai dari titik pengumpulan terakhir dari suatu siklus pengumpulan sampai ke TPA. Menurut Damanhuri (2010) pengangkutan sampah adalah sub-sistem yang bersasaran membawa sampah dari lokasi pemindahan atau sumber sampah secara langsung menuju tempat pemrosesan akhir, atau TPA. Menurut Balai Air Minum dan Sanitasi (2010) peralatan pengangkutan yang dapat digunakan untuk mengangkut sampah memiliki syarat diantaranya alat pengangkut sampah harus dilengkapi dengan penutup sampah, minimal dengan jaring, tinggi bak maksimum 1,6m, sebaiknya ada alat ungkit, kapasitas disesuaikan dengan kelas jalan yang akan dilalui, dan bak truk/dasar container sebaiknya dilengkapi pengaman air sampah. Sedangkan menurut Balai Air Minum dan Sanitasi (2010) jenis peralatan yang dapat digunakan berupa:

\section{a. Dump truck \\ b. Arm roll truck \\ c. Compactor Truck \\ d. Trailer Truck}

Pengangkutan sampah dapat dilakukan dengan berbagai cara, metode dan peralatan yang digunakan tergantung dari pola pengumpulan yang digunakan. Beberapa pengangkutan berdasarkan pola pengumpulan sampah diantaranya:

1. Pengangkutan sampah pada pengumpulan dengan pola individual langsung

2. Pengangkutan dan pengumpulan dengan pola individual tidak langsung

3. Pengangkutan sampah dengan sistem container angkat

4. Pengangkutan sampah dengan sistem container ganti

\section{METODE PENELITIAN}

Jenis penelitian ini adalah penelitian lapangan (field research) yang menggunakan kehidupan nyata sebagai tempat kajian. Pendekatan penelitian dilakukan melalui pendekatan kualitatif, dimana data berasal dari pedoman wawancara, pengamatan dan dokumen resmi lainnya. Pendekatan kualitatif dalam penelitian ini lebih diarahkan pada realita dengan teori dengan menggunakan metode deskriptif.

\section{Prosedur Pengumpulan Data}

Prosedur pengumpulan data dilakukan sebagai berikut :

1. Wawancara (Interview); dilakukan dengan mengajukan beberapa pertanyaan dan yang diwawancarai memberikan jawaban atas pertanyaan itu.

2. Pengamatan (Observation); dilakukan dengan melihat dan mencatat tentang objek penelitian. Adapun pengamatan dibuat dalam pedoman pengamatan dengan topik Analisis Sistem Pengangkutan Sampah Rumah Tangga di Jalan Garuda Kota Palangka Raya.

3. Dokumentasi (Document); prosedur pengumpulan data dengan dokumentasi akan diverifikasi yang sesuai dengan objek penelitian.

\section{Analisis Data}

Proses analisis data dimulai dengan menelaah seluruh data yang tersedia dari berbagai sumber, yaitu dari wawancara, pengamatan yang sudah dituliskan dalam catatan lapangan, dokumen pribadi, dokumen resmi, gambar, foto dan sebagainya. Setelah dibaca dipelajari, ditelaah, maka selanjutnya ialah mereduksi data yang dilakukan dengan 
jalan membuat abstraksi. Abstraksi merupakan usaha membuat rangkuman yang inti, proses, dan pernyataan-pernyataan yang perlu dijaga sehingga tetap berada di dalamnya.

Langkah selanjutnya adalah menyusunnya dalam satuan-satuan. Satuansatuan kemudian dikategorisasikan pada langkah berikutnya. Kategori-kategori itu dilakukan sambil membuat koding. Tahap akhir dari analisis data ini ialah mengadakan pemeriksaan keabsahan data.

\section{HASIL DAN PEMBAHASAN}

\section{Ulasan Sistem Pengangkutan Sampah Rumah Tangga di Jalan Garuda Kota Palangka Raya}

Tempat Pembuangan Sampah sementara di jalan Garuda Terdiri dari 2 TPS, diantaranya berada di jalan Garuda I dan di jalan Garuda Induk Kota Palangka Raya, untuk TPS di jalan Garuda Induk mengunakan kontainer yang sistem angkutnya mengunakan Arm roll truck, yaitu kendaraan angkut yang dilengkapi sistem hidrolis untuk mengangkat bak dan membongkar muatannya. Dengan jumlah petugas sebanyak 5 orang dan ditambah sopir 1 orang. Truk ini memiliki kapasitas $8 \mathrm{~m}^{3}$. Agar tidak mengganggu lingkungan selama perjalanan ke TPA, container ini memiliki tutup dan tidak rembes sehingga tidak mudah tercecer.

Sementara Pengengkutan sampah mengunakan Dump Truck adalah kendaraan angkut yang dilengkapi sistem hidrolis untuk mengangkat bak dan membongkar muatannya. Pengisian muatan masih tetap secara manual dengan tenaga kerja, yaitu tenaga kerja sebanyak 5 orang di tambah sopir sebanyak 1 orang. Truck ini memiliki kapasitas $8 \mathrm{~m}^{3}$. Agar tidak mengganggu lingkungan selama perjalanan ke TPA, Dump truck ini dilengkapi dengan tutup terpal. (hasil wawancara dengan pegawai kebersihan kota Palangka Raya)

Secara visual dilapangan terlihat, adanya sampah-sampah masih berhamburan diluar kotak penampungan sampah sementara maupun diluar kontainer yang disediakan, sehingga menimbulkan pencemaran lingkungan seperti bau tak sedap, pandangan mata yang tidak nyaman dan lalat yang semakin banyak.

\section{Penyelesaian Masalah}

Penyelesaian masalah analisis K3 pada sistem pengangkutan sampah di TPS ini adalah perlu dilakukan suatu data penilaian yang terukur untuk menentukan tingkat keberhasilan dalam penangan pengangkutan sampah di TPS seputaran jalan Garuda Kota Palangka Raya, melalui data pengamatan (observation) dan wawancara (interview) seperti pada Tabel 3 dan 4 .

Tabel 3. Data Pengamatan (Observation) K3

\begin{tabular}{|c|c|c|c|c|}
\hline \multirow{2}{*}{ No } & \multirow{2}{*}{ Butir-butir yang Diamati } & \multicolumn{2}{|c|}{$\begin{array}{c}\text { Hasil } \\
\text { Pengamatan }\end{array}$} & \multirow{2}{*}{$\begin{array}{c}\text { Tingkat } \\
\text { Keberhasilan }\end{array}$} \\
\hline & & Ada & $\begin{array}{c}\text { Tidak } \\
\text { Ada }\end{array}$ & \\
\hline 1 & Rambu-rambu lalu lintas & $\sqrt{ }$ & - & Berhasil \\
\hline 2 & Spanduk K3 dari PT. Jamsostek & - & $\sqrt{ }$ & Tidak Berhasil \\
\hline 3 & $\mathrm{P} 3 \mathrm{~K}$ & $\sqrt{ }$ & - & Berhasil \\
\hline \multirow[t]{6}{*}{4} & Alat pelindung diri & & & \\
\hline & a) Baju kerja & $\sqrt{ }$ & - & Berhasil \\
\hline & b) Sarung tangan & $\sqrt{ }$ & - & Berhasil \\
\hline & c) Sepatu & $\sqrt{ }$ & - & Berhasil \\
\hline & d) Helm kerja & - & $\sqrt{ }$ & Tidak berhasil \\
\hline & e) Masker & $\sqrt{ }$ & - & Berhasil \\
\hline 5 & Sosialisasi K3 & - & $\sqrt{ }$ & Tidak berhasil \\
\hline 6 & Himbauan-himbauan K3 & - & $\sqrt{ }$ & Tidak berhasil \\
\hline 7 & Petugas Keamanan & - & $\sqrt{ }$ & Tidak berhasil \\
\hline
\end{tabular}

\section{Berdasarkan hasil pengamatan} (observation) pada Tabel 3 dan wawancara (interview) pada Tabel 4 terlihat, memiliki nilai butir yang sama yaitu telah memiliki rambu-rambu lalu lintas, $\mathrm{P} 3 \mathrm{~K}$ dan alat pelindung diri seperti baju kerja, sarung tangan, sepatu, masker, Namun untuk butir Spanduk K3 dari PT. Jamsostek, alat pelindung diri (helm), sosialisasi K3, himbauan-himbauan K3 dan petugas keamanan terlihat belum dimiliki. Sehingga, dari 7 (tujuh) butir penilaian, bahwa ramburambu lalu lintas, alat pelindung diri seperti baju kerja, sarung tangan, masker dan sepatu kerja yang berhasil dalam upaya pencegahan kecelakaan kerja. Sedangkan, spanduk K3 dari PT. Jamsostek, alat pelindung diri (helm), sosialisasi K3, himbauan-himbauan K3 dan petugas keamanan terlihat belum berhasil dalam upaya pencegahan kecelakaan kerja. Sehingga, secara keseluruhan, bahwa penerapan K3 di pengangkutan sampah ini kurang berhasil dalam upaya pencegahan kecelakaan kerja.

Menurut Pedoman Pedoman

Pelaksanaan Keselamatan dan Kesehatan 
Kerja (K3) untuk konstruksi jalan dan jembatan, Departemen Pekerjaan Umum (2006) pada point 4.1.1, bahwa penerapan K3 di pengangkutan sampah ini masih kurang berhasil dalam upaya pencegahan kecelakaan kerja. Kurang berhasilnya penerapan K3 di pengangkutan sampah ini sebagian besar belum didukung peralatan lingkungan kerja seperti spanduk K3 dari PT. Jamsostek, alat pelindung diri (helm), tidak adanya sosilisasi K3, kurangnya himbauan-himbauan K3 dan belum adanya petugas keamanan sehingga tenaga kerja tidak terlindungi dari resiko kecelakaan hal ini dikarenakan pengangkutan sampah dilakukan pada malam hari pukul 21.00 WIB maupun subuh jam 03.00 WIB

Menurut Hinze, 1997 (dalam Christina WY dkk, Jurnal Rekayasa Sipil, Vol.6, No.1, 2012), bahwa penerapan K3 di Paket ini juga kurang berhasil dalam upaya pencegahan kecelakaan kerja. Kurang berhasilnya penerapan K3 di pengangkutan sampah ini belum didukung keterlibatan secara aktif dari manajemen perusahaan bagi terciptanya perbuatan dan kondisi lingkungan yang aman. Kemudian lagi, belum terlihat adanya komitmen bersama untuk menjalankan K3 demi terciptanya keamanan di lakasi pengangkutan sampah ini.

\section{Solusi}

Ada beberapa solusi yang dapat digunakan untuk mencegah atau mengurangi resiko kecelakaan kerja di pengangkutan sampah di Kota Palangka Raya ini yaitu dengan menugaskan secara khusus Ahli K3 dan tenaga K3. Tenaga K3 ini harus masuk dalam struktur organisasi di pengangkutan sampah ini dengan ketentuan :

1. Petugas keselamatan dan kesehatan kerja harus bekerja secara penuh (full-time) untuk mengurus dan menyelenggarakan keselamatan dan kesehatan kerja.

2. Pengangkutan sampah ini mempekerjakan pekerja masih dibawah 100 orang atau sifat kegiatan ini memang memerlukan, diwajibkan membentuk unit pembina K3.

3. Memiliki komitmen bersama untuk mencegah kecelakaan tenaga kerja dengan melengkapi penunjang keamanan yang bersifat material seperti helm, kaca mata, sarung tangan. Kemudian, pencegahan kecelakaan kerja yang bersifat non material seperti buku petunjuk penggunaan alat, sosialisasi K3, himbauan-himbauan K3 dan adanya petugas keamanan.

Solusi yang lain adalah tenaga kerja yang akan bekerja sebaiknya ditempatkan berdasarkan keahlian dan pengalaman masing-masing agar produktivitasnya lebih maksimal, tenaga kerja hendaknya berstatus pegawai tetap agar merasa lebih tenang dalam bekerja, mewajibkan penggunaan alat pelindung diri seluruh tanaga kerja, memasang papan petunjuk K3 dengan semboyan "lebih baik mencegah dari pada mengobati" dan mengikuti pelatihan K3 seluruh tenaga kerja dengan secara bertahap, sehingga tenaga kerja telah diupayakan agar terhindar kecelakaan kerja.

\section{KESIMPULAN}

Berdasarkan hasil penelitian, maka dapat diberi kesimpulan antara lain :

1. Penerapan K3 pada penelitian ini hanya berhasil dalam upaya pencegahan kecelakaan kerja dengan dukungan adanya rambu-rambu lalu lintas, dan alat pelindung diri seperti baju kerja, sarung tangan, septu kerja, dan masker .

2. Ada penerapan K3 yang belum didukung, tidak ada sosilisasi K3, kurangnya himbauan-himbauan K3 dan tidak ada petugas keamanan masih kurang berhasil. Namun, secara keseluruhan, bahwa penerapan K3 Pada Pengangkutan Sampah Rumah Tangga di Jalan Garuda Kota Palangka Raya ini dianggap cukup berhasil dalam upaya pencegahan kecelakaan kerja.

\section{SARAN}

Berdasarkan kesimpulan, maka diberi saran-saran sebagai berikut :

1. Untuk pencegahan kecelakaan kerja sebaiknya melengkapi semua alat pelindung diri (baju kerja, sarung tangan, sepatu dan helm), melakukan sosialisasi $\mathrm{K} 3$, himbauan K3 dan petugas keamanan.

2. Upayakan komitmen bersama dalam menjalankan K3. 
3. Membuat aturan atau sanksi dalam menjalankan K3 sehingga diharapkan dapat mencegah tidak ada kecelakaan kerja atau nol kecelakaan (zero accident).

\section{DAFTAR PUSTAKA}

SNI 19-2454-2002. Tata Cara Teknik Operasional Pengelolaan Sampah Perkotaan Badan Standarisasi Nasional, Jakarta.

Suparmi, A., 2009, Optimasi Pola Pengumpulan Dan Pengangkutan Sampah Kota Muara Teweh Melalui Pendekatan Zonasi. Semarang. (http://www.sanitasi.or.id/ppsp/wp.cont ent/uploads/pdf/persampahan/materi1/7 _pengangkutan_sampah.pdf.). Diunduh pada tanggal 10 november $2013,09.54$ WIB.
Joseph, C., 2011, Analisis sistem Pengangkutan Sampah Kota Makasar Dengan Metode penyelesaian Vehicle Routing Problem (VRP). (http://repository.unhas.ac.id/bitstream/ handle/123456789/460/TA\%20LENGK AP.pdf?sequence $=2$.) diunduh pada tanggal 6 Oktober 2013,16.35

Damanhuri, E., 2010, Diktat Kuliah Teknik Lingkungan, ITB, Bandung.

Maharini, D., 2010, Upaya Dinas Kebersihan Dan Pertamanan dalam Pengelolaan Sampah di Kota Surabaya. Diunduh 6 Agustus 2014, 10:38 WIB. 